\title{
Is it legally possible to set forest fires for scientific purposes?
}

\author{
Yavuz GÜLOĞLU' ${ }^{1 *}$, Nur BELKAYALI ${ }^{2}$, Alper BULUT ${ }^{3}$ \\ ${ }^{1}$ Kastamonu University, Faculty of Economics and Administrative Sciences, Kastamonu, TURKEY \\ ${ }^{2}$ Kastamonu University, Faculty of Engineering and Architecture, Kastamonu, TURKEY \\ ${ }^{3}$ Kastamonu University, Faculty of Forestry, Kastamonu, TURKEY \\ *Corresponding author: yavuzguloglu @ kastamonu.edu.tr
}

Received Date: 01.02.2017

Accepted Date: 09.11.2017

\section{Abstract}

Aim of study: The aim of the study comprises the examination of permissions to be given by forest administration about forest fires for scientific purposes in the lights of current legislation provisions and administrative law, and the development of effective strategies on providing a solution.

Area of study: The study comprises all fires that are set purposely, intentionally and recklessly for scientific purposes in Turkey.

Material and Methods: The main material of the study is legislation in force, concerning forest fires in Turkey. On the other hand, the method of the study is to determine the relevance of fires with current legislation provisions in order to identify legal characteristic of forest fires for scientific purposes.

Main results: When current legislation provisions are taken into consideration, it is observed that forest administration is not authorized to give permission to set fires even for scientific purposes in forest areas and there are not any legal regulations that give permission to the administration to take action in this direction, as well. In the event of giving permission to such an action, legal and penal obligations would arise to the public official who gives permission.

Research highlights: Regulations should be made to fill legal gaps in order to prevent civil and criminal liability about the administration and the agent of the administration who permit forest fires to be carried out for scientific purposes. Moreover, the authority of giving permission should not be given a single person but a commission with this legal regulation.

Keywords: Forest fire, Crime, Administrative leave, Compliance with law

\section{Bilimsel olarak orman yangını gerçekleştirmek yasal olarak}

\section{mümkün müdür?}

Özet

Çalışmanın amacı: Bilimsel amaçlarla orman yangınlarının gerçekleştirilmesi hakkında ormancılık yönetiminin vereceği izinlerin, yürürlükteki mevzuat hükümleri ve idare hukuku ilkeleri işığında incelenmesi ve çözüm sunma konusunda etkili stratejiler geliştirilmesi, bu çalışmanın amacını oluşturmaktadır.

Çalışmanın alanı: Bu çalışma, Türkiye'de bilimsel amaçlarla, ormanlarda yangın çıkarılmasına yönelik olarak bilerek, isteyerek ve taksirle çıkartılan tüm yangınları kapsamaktadır.

Materyal ve yöntem: Çalışmanın ana materyalini, Türkiye'de orman yangınlarına ilişkin uygulanan meri mevzuat oluşturmaktadır. Öte yandan araştırmanın yöntemi, bilimsel amaçlı orman yangınlarının hukuki niteliğini belirlemek için bu faaliyetlerin yürürlükteki mevzuat hükümlerine uygunluğunun saptanmasıdır.

Sonuçlar: Yürürlükteki mevzuat hükümleri göz önünde bulundurulduğunda, orman idaresinin ormanlık alanlarda bilimsel amaçlarla olsa dahi ormanı yakmaya izin vermeye yetkisi olmadığı, ayrıca bu yönde idareye işlem yapmaya izin veren herhangi bir yasal düzenleme olmadığı görülmektedir. Böyle bir işleme izin verilmesi durumunda, izin veren kamu görevlisine hukuki ve cezai yükümlülükler doğabilecektir.

Araştırma vurguları: Bilimsel amaçlarla orman yangını gerçekleştirilmesine izin veren idare ve idarenin ajanı hakkında, hukuki ve cezai sorumluluk doğmaması için hukuki boşlukların doldurulmasına yönelik düzenlemeler yapılmalıdır. Ayrıca yapılacak bu yasal düzenlemeyle izin verme yetkisi, sadece tek bir kişiye değil bir komisyona verilmelidir.

Anahtar kelimeler: Orman yangını, Suç, İdari izin, Hukuka uygunluk 


\section{Introduction}

One of the most important factors which threaten the forests in Turkey is forest fires, as is the case in most of the world. Forest fires affect considerable part of the forest lands and habitats around the world every year and cause a significant amount of spending on fire fighting, loss of life, property as well as recreational values and loss of wildlife (Evcin et al., 2014). Forest fires (wildfires) are a repetitious disturbance in the Mediterranean Land (Catrya et al. 2010). The forests of Turkey which are located in Mediterranean geography and climate zone are under a serious fire threat especially in summer, and significant amount of forests are lost due to the forest fires almost every year. 1,662,024 hectares of land were burned from 1937 to 2017. According to this, the overall average burning area per year is 20,775 hectares. The area per fire is 15.94 hectares. Figure 1 shows the number of forest fire distributions according to years (Orman Genel Müdürlüğü, 2017).

There are two types of forest fires in Turkey, namely surface fires and crown fires. Surface fires burn the surface, both litter and live surface, which covers the forest soil. Forest fires for scientific purposes are started on the surface. Even though it is argued that the surface fire does not damage stand original trees, but only cause damage in the event of intensive flammable materials covering the soil, the trees in forests sometimes lose their vitality. Crown fire spreads by burning the top of trees and shrubs. As for this type of fire, since the forest land, tree trunks and tree tops burn at different intensity, except for some exemptions, the trees often dry and the stand loses its liveliness. This is the most dangerous type of fire (Akkuzu et al., 2012).
Forest fires have different behaviours depending on where they occur, the fuels they burn and its influencing factors (Küçük and Aktepe, 2017). The fuels are different from meteorological and topographic factors which cannot be controlled any how as the fuels may vary in terms of time and place and can be taken under control (Küçük et al., 2005). The fires burn, spread and release energy. These features of forest fires contributed by environmental effects are called fire behaviours. The factors affecting the fire behaviour are topography, fuel features and weather (Bilgili et al., 2002). If the fire fighting teams are well aware of the mentioned three factors, appropriate strategies will be developed in time, extinguishing will be organized this way and fire fighting will be better (Eron, 1988).

Fire management plans include protective and preventive measures to be taken before a fire planning firefighting, evaluating the effects of fire and using fire as a management tool. Organisation of fire extinguishing teams and distribution of resources can be planned in the most efficient way through fire behaviour scenarios developed for critical areas regarding fire danger (Bilgili, 1998; Akkaş et al., 2008). Fire managers need any location-related information affecting fire behaviour while they are making a decision in fire management. Such data play an important role in revealing the fire potential and estimating fire behaviour. Quantitative fire danger maps and fire behaviour maps are developed by using advanced technology. The fire behaviour map is a significant tool in following the location of the fire development, deploying firefighting teams and determining the place and method of response (Küçük and Bilgili, 2007). 


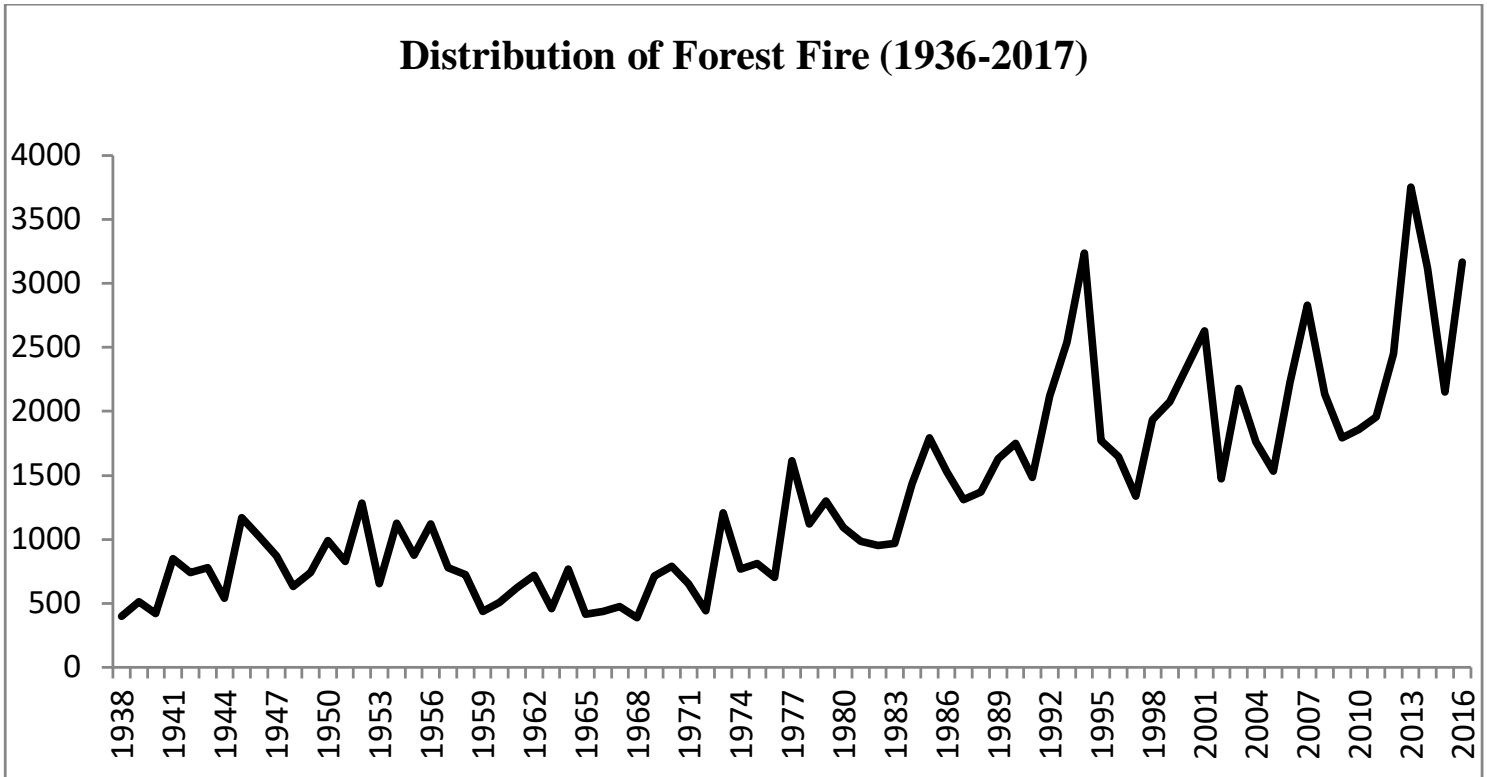

Figure 1. Distribution of Forest Fire from 1936 to 2017

In countries which effectively fight against forest fires such as Turkey, the fire is left to its natural course, and the aim is to prevent it from spreading, to prevent any fire even before it starts and extinguish it at the shortest time. With the aim of effective fight against forest fires and response to forest fires at the shortest time, fire managers will make almost-real forecasts regarding the fire potential and fire behaviour by using fire potential maps, fuel maps, climate and fire development maps, and thus, they will ensure that the necessary measures are taken before, rather than extinguishing the fire, by predetermining the fire possibility through decision support systems (Bilgili et al, 2002).

Success of the fire organization depends on a sound forecast of the fire behaviour under the existing conditions and whether the fire potential is accurately and timely revealed. With a view to making accurate forecasts, forestry administration carries out some transactions for allowing burning the forest for scientific purposes within the boundaries of the forest. A successful fight against forests is only possible by timely taking necessary measures and by also using advanced technology at every stage of the fire process, not by efficient and effective utilization of the resources. These tools will also be used in extinguishing future fires, and thus, the fire behaviour will be determined by burning a small piece of land, and modern techniques and methods will be used in extinguishing forest fires and preventing larger ones. With fire behaviour models which fit the conditions in Turkey, fire danger rating system and fire decisionsupport system should be established.

This study evaluates whether it is possible for the forestry administration to allow burning a part of forest area for scientific purposes within the framework of the applicable legislation on forests, the status of such a permission against the penal provisions in the legislation and the constitutional provisions protecting the forests and environmental right.

\section{Competent Authority for Protecting and Operating Forests and the Limits of its Power}

Pursuant to article 169 of the Turkish Constitution, the Government is authorized to supervise all forests, and it is the duty of the Government to enact laws and take measures with the aim of protecting the forests and expanding the lands, and to grow new forests in the place of those burned. According to the law, state forests are managed and operated by the State. Any act or action that may damage the forests is not allowed. General amnesty or pardon cannot be granted exclusively for forest crimes. The crimes aiming at burning, destroying or 
narrowing forests are not taken under the scope of general amnesty or pardon.

According to article 6 of Forest Law no 6831 regarding forest regime which is shaped by the Constitutional provisions above, the authority to perform any act or action regarding the state forests in Turkey is vested to the General Directory of Forestry by virtue of the provision, "Any work pertaining to state forests and any place deemed State forest shall be done or cause to be done by General Directory of Forestry."

Pursuant to article 15 of Forest Law No. 6831, "Except for the operations by the administration for scientific purposes with the aim of development of the forest, the following is subject to the permission of the administration: to uproot seedlings or cut branches which are stated in subparagraph (A) of article 14, to perform the acts listed in subparagraph (B) to get forest proceeds and to perform the acts listed in subparagraph (C) with the aim of getting various benefits." As it is clear in the text, this article of Forest Law is created with the aim of ensuring further development of the forests (Aras, 2013). According to the Law, forestry administration is authorised to grant permission for the work stated in article 14 of the Law for the development of the State forests, as a result of its technical intervention within the framework of the management plans. This includes the permissions aiming at benefiting from the seedlings and forests somehow, and it is not directed towards uprooting the seedling and damaging forests. Likewise, Forest managers may allow truncating the tree branches or cutting and transferring them to another place with the aim of taking measure against fires, insects and other pests. The reason for not making any arrangement under article 15 regarding the provisions in subparagraphs (D) and (E) of article 14 is that it is forgotten in the later amendment of the law. Thus, it is agreed in practice that the acts listed in subparagraphs (D) and (E) of article 14 can be performed only after the relevant permission is taken from forestry administration (Aras, 2013). These interventions contribute to the development of the forest and do not harm the vitality of the trees.
As it is clear, the purpose of the mentioned provisions of the Law is to protect the forest existence, improving its quality, to ensure its sustainability, and to transfer to another place the branches and snags of the trees which are likely to be harmed for any reason and to use them for a better purpose.

\section{The Authority of the Administration to Arrange and Allow in the Context of Legality of the Administration}

According to Gözler (2009) and Yildırım et al. (2015) "Legality of the administration has two separate meanings. First of all the transactions and acts of the administration must be statutory. Secondly, these transactions and acts must be in compliance with law". As required by the "essentialness of the legislative prerogative principle" in Turkey, the parliament does not have to base its legal arrangements on a Constitutional provision while it is making law. It is sufficient that the legal arrangements made by the Parliament are not in conflict with the Constitution (Özbudun, 2004). This is also a natural result of the monist state and unity of the administration principles. In spite of this, the administration cannot act in a field which is not arranged by the legislative body before, and it must hold the authority vested by the law in order to be able to perform an administrative action (Günday, 2015). The administration staying within the boundaries set by the law is also called "respect for law" (Balta, 1970). For the issues which are envisaged by the Constitution to be governed in a law, it is impossible to vest to the executive body a general arrangement authority with no limits set. Arrangement power of the executive body is a limited, complementary and dependant power. Therefore, except for the cases stated in the Constitution, the executive body cannot be granted the power to set general rules in the fields which are not governed by a law. In addition, in order that a legal rule which grants arrangement power to the executive body is in line with article 7 of the Constitution, fundamental principles and the framework must be set, and no wide area should be left vague and without any limit. (Constitution Court: 07.07.2014 E:2010/69, K:2011/116) 
The rule included under article 8 of Turkish Constitution which reads "The power and duty of execution shall be exercised and carried out in compliance with laws" and the rule included under article 123 of Turkish Constitution which reads "The administration... shall be arranged by law together with its establishment and duties", is the reflection of the legal administration principle on the written rules. There is no administration where there is no law (Güneş, 1965). The administration must act in compliance with the laws while fulfilling its duties assigned by law. The administration should not be able to exercise any power which is not based on Constitution and law, even if there is no prior arrangement on a certain issue, because the power to make arrangement on such issue belongs to the legislative body. The execution is defined in Constitution of 1982 as both a power and a duty, which means that it is a field of activity where the Executive and the Administration may act even in the absence of a legal power. As stated in article 2 of the Constitution, one of the fundamental principles of state of law is "certainty". According to such principle, the legal arrangements must be clear, certain and understandable in a way that will not cause any hesitation and suspect, in terms of both persons and administration, and they must also include preventive measures against the arbitrary practices of the public authorities. Certain principle is connected with the legal security, and the person should know which concrete action or phenomenon is connected to which legal sanction or consequence, and which intervention powers are vested to the administration for this purpose. Legal security requires predictable norms and that the persons can rely on the state regarding all their acts and actions and that the state avoids any method which may damage such confidence in legal arrangements (Constitution Court 26.12.2013 and E.2013/67, K2013/164). It is argued that the challenges of life, diversity of social relations and huge number of administration duties cannot be suggested as a justification for uncertainty, and thus, lack of legal security (Can, 2005). The State must create a state of law with legal security with a view to ensuring personal development, both material and spiritual (Akyılmaz, 2000, Akyılmaz et al., 2009). However, it is inevitable to grant some freedom to the administration given that it may be impossible, although everything may be legally arranged. Nevertheless, the administrative duties in the fields which require technical knowledge and expertise and which become quite complicated because of such freedom, may be executed at a level that meets the needs of the modern society modern (Günday, 2015).

If the transactions and actions carried out by the administration intend to restrict the fundamental rights and freedoms governed in article 13 of the Constitution, these restrictions have to be based on a law. Otherwise, it is impossible to restrict fundamental rights and freedoms. However, legal arrangement envisaged by European Convention on Human Rights, laws, regulations, by-laws, settled case law of any kind, etc. are the transactions which introduce intangible norms (Erdoğan, 2012), provided that they are accessible (Gölcüklü and Gözübüyük, 2002). This kind of interpretation falls behind the national assurances (Can, 2005). When legal certainty principle is taken not as a statutory certainty alone but together with other arrangements, if its legal ground is laid down, i.e. the issue is governed in some arrangements such as regulation, by-law, circular, this may not be in conflict with legal certainty principle.

In the light of the explanations above, can the administration allow setting the forest land on fire for scientific purposes despite of the absence of any power vested to it by Forest Law no. 6831? It is more appropriate to answer this question after examining the provisions in Forest Law on the sanctions against setting the forest on fire.

\section{Starting Fire in the Forest with the Permission of the Forest Administration}

Starting fire in the forest, to the knowledge of the forest administration, may be examined under three titles, namely starting tentative fire in the forest for scientific purposes, making fire for picnic in the places allowed and assigned by the forest administration, and allowing making fire in the forest within the scope of pest control. 


\subsection{Allowing Setting the Forest on Fire for Scientific Purposes}

Forest Law no.6831 defines forest as "a set of trees and shrubs grown either naturally or by human efforts, together with their land". The law considers as forests not only the trees but also the land they are located on, thus even if the trees disappears due to a fire etc. the land is still considered a forest. Furthermore, the definition of forest is very comprehensive in a way that it includes not only the trees, but also the microorganisms, plants and animals living in the forests. It is possible to benefit from the forests listed among the unclaimed public goods (Gülan, 1999) in line with the provisions on not damaging the forest and allowing benefiting from it. However, forest administration which presents public service (Gülan, 1988) and which is charged with its protection should not allow any act which may damage the forests.

In the event of a fire caused on any land, relevant provisions of Turkish Penal Code, as a general law, will be applied, but if a fire is caused on a forest land, the provisions of Forest Law, a specific law, will be applied.

Considering the penal clauses of Forest Law no. 6831 on causing and extinguishing forest fires, according to article 76, the following are prohibited and requires imprisonment and administrative fine:

a) To throw away to the forest glowing cigarette or any substance that may indirectly cause a fire,

b) To burn stubbles or other similar vegetation four kilometres away from forests or within the boundaries of the villages falling under the scope of articles 31 and 32 of the Law,

According to article 110 of Forest Law;

- Those causing a forest fire because of lack of attention and care are sentenced to two to seven years imprisonment,

- Those setting a forest on fire deliberately are punished with heavier imprisonment and administrative fine,

- Those setting a forest on fire within the framework of an act of the organization established with the aim of committing a crime against the state security are sentenced to penal servitude for life and administrative fine.

This arrangement prohibits any act that causes forest fire, be it involuntary, deliberately or for terror purposes. It is horrible even to image that the forest administration and a public officer working in such administration setting a forest on fire. It is almost impossible for a public officer, who is working in an institution charged with protecting the forest and increasing forest existence, to act this way. However, allowing starting a fire in a forest land even for scientific purposes in the absence of a law allowing such act may constitute crime of deliberately setting forest on fire. Likewise, if the forest is burnt out as the fire started deliberately on a no-forest land by taking permission spreads to a forest land after failing to extinguish the one started deliberately, this may result in deliberately causing forest fire.

The Forest Law has some provisions which punish even not responding to forest fire, let alone causing a forest fire.

Pursuant to article 68 of the Law, those seeing any sign of fire, either in or around the forest, are obliged to inform the forest administration thereof.

Pursuant to article 69 of the Law, all the man population between the ages of 18 and 50 from villages and towns around the forest are obliged to go the fire area and to support the fire extinguishing team together with the equipment used in fire extinguishing, and if these people are not sufficient for extinguishing the forest fire, then the ones under the same obligation from adjacent towns and villages as well as a few administrations are sent to the site as well,

Pursuant to article 73 of the Law, station officers are obliged to take those who will extinguish the fire to and from a place close to the fire.

In the light of the articles above, setting the forest on fire deliberately or recklessly, and not responding to a burning forest land constitute crime. Considering the forest firerelated provisions of the Law from this point of view, even not informing or responding to the already started fire is accepted as a crime; therefore, starting a fire for any reason may constitute a crime. Any action related to 
preventing and extinguishing forest fires is executed in compliance with "Communique on Code of Practice regarding Preventing and Extinguishing the Forest Fires no. 285" which took effect on 01.01.1995. Furthermore, the duties of and services to be provided by the officers and those liable in preventing and extinguishing the forest fires are governed in "By-law on the Actions to be Performed by the Officers in Preventing and Extinguishing Forest Fires" which is arranged pursuant to article 69 of Law No. 6831. These arrangements do not have any provision of allowing such kind of action.

\subsection{Burning fire at the places authorized by the Forestry Administration}

Pursuant to article 76 of Law no. 6831, "It is prohibited, in the forests, to start fire at any place other than the assigned fireplaces, or leaving the location without extinguishing the fire started in assigned places."

A special legal regulation which is related to the provision of starting a fire action is particularly considered to be related to the Gallipoli National Park. This legal regulation was examined by the Constitutional Court in detailed. The court has been discussed that starting a fire at any place other than those assigned by the administration for only picnic purposes should not be defined as a crime in any laws. Furthermore, it has been argued that the punishment for this reason should not be excessive for the concept of penal and criminal policies. It also should not disturb a sense of justice. In this concept, the Constitutional Court made the decision of 10.2.2004 no. E:2001/143 K: 2004/11 which is the request of cancelling the arrangement in subparagraph (b) of the first paragraph of article 6 in "Gelibolu (Gallipoli) Peninsula Historical National Parks Law no. 4533" which reads, "to make fire at any place other than the assigned places and to leave the location without extinguishing the fire made in the assigned places". In this court decision, an arrangement involving the Gelibolu National Park which witnessed one of the biggest wars in history and which still honours the memories of hundred of thousands losing their lives in the war without making discrimination among the nations is made. The region should be taken under protection due to the following three disadvantages; the region is open to high winds and thus inadequacy of the general provisions in protecting the region, and also it has witnessed a big forest fire in the past. Along with its vicinity, and that making those benefiting from Gelibolu National Park and those benefiting from other regions having characteristics different from this region be subject to the different legal rules is not in conflict with the principle of equality.

With the decision of Commission of Fire Managers, picnic in the forests other than forests assigned for picnic, making fire in forests even if it is a picnic area, and entry to and exit from the plantation and regeneration areas which are determined as sensitive to forest fires, by anyone other than the staff for any purpose, may be restricted and even prohibited for the purpose of preventing any possible forest fires and ensuring safety of life and property.

\subsection{Burning the Litter in the Forest}

Surface fire defined in "Communique on Code of Practice regarding Preventing and Extinguishing the Forest Fires no. 285" is the fire which burns the surface covering the forest land, either litter or alive.

Within the scope of controlled fire practices which are sometimes used as a silvicultural tool or a forest protection tool in forestry practices, the litter in the forest is burnt by the forest administration with the aim of:

-Cleaning the materials by burning left from the trimmed old stands which are mature enough to be cut in the areas where natural or artificial regeneration will be made,

-Removing the thick mould layer on the soil and ensuring that the spilt seeds reach the mineral soil in the places where litter hinders natural regeneration,

-Encouraging and giving priority to natural regeneration of the desired species in the appropriate stands where natural change in species is possible,

-Increasing the development of some bush species whose leaves and suckers can be used as feed,

-Eliminating, in natural meadows, undesirable species which are competing 
with the herbaceous and bush vegetation whose feed value is high, and removing the dry materials which may increase fire risk (Şengönül, 1985). Prescribed burning on forest lands can be organized in more favorable conditions and within loose hazard limits. As the most common purpose of controlled burning in forest lands is often to decreasing the surface fuels, it is argued that waiting favourable conditions for controlled burning and carrying out this in a relatively humid season is beneficial for the forest and that it does not damage the original trees of the stand. Surface fire may damage the forest in the event of intensive fuels covering the soil. Therefore, burned area should be monitored and controlled after the fire.

However, control fire may sometimes cause unexpected serious mistakes which may sometimes result in forest fires.

Many plant species that we encountered in an unburned forest or bush at very low density may become dominant in the field after the surface fire (Tavşanoğlu 2010). But as a result some herbs, grass, brier, seedling, saplings and other living creatures in the forests are also burnt with surface fires. This may conflict with some international arrangements which Turkey is a party to such as Biological Diversity Convention. However, the comparison between the benefit expected from burning the litter and protecting the biodiversity in the forest should be made well. If the financial possibilities of the state forest administration enable removing the litter without burning, it would be more appropriate not to use this method. Furthermore, even if it is a controlled way of burning, this act may sometimes cause a forest fire in an instant, and thus, burn the forest due to an instantaneous change in natural events, in which case, the forest administration personnel who has performed such act may be punished for causing forest fire recklessly, if not for burning the forest on purpose.

\section{Evaluation}

In the action for nullity filed with the argument that the administrative action stated in article 2 of Administrative Trial Procedure Law no.2577 titled "Types of Administrative Lawsuits and the Limits of Administrative
Lawsuits" is in conflict with the law in terms of power, reason, subject, purpose and form, the administrative actions are subject to examination by the judicial authorities since they are contrary to these components. Because of the principle of legal administration and foreseeable administrative actions, it is believed that the administration is not authorized to allow burning the forest for scientific purposes despite the measures taken and isolations made in and around the forest. However, a negative answer should be given to the following question: Is it possible for the administration to make an arrangement which will constitute the legal basis for allowing the action through a general regulatory arrangement such as a bylaw. Besides, such an arrangement will be in conflict with the provision in article 169 of the Constitution which reads, "No action or activity can be allowed which may damage the forests." Yet such arrangement is not made with the aim of damaging the forests, but on the contrary to set the measures which should be taken in order to prevent burning out larger forest lands in the event of bigger fires. However, it is believed that the administration does not have such a power given the rule clearly governed in the Constitution with regard to protecting the forests. Nevertheless, making an arrangement for allowing starting fire in forest land for scientific purposes, even if it is contrary to the Constitution, will be adequate to ensure legal certainty. In addition, allowing forest fire as based on such an arrangement may be considered among the reasons for compliance with the laws governed in penal law.

If a forest land larger than planned is burnt out as the fire started deliberately on a certain land, as based on an arrangement allowing starting a forest fire for scientific purposes, spreads to other areas after failing to extinguish the one started deliberately, those causing and allowing the fire may be charged with recklessly causing forest fire or deliberately starting forest fire. Because intend which is among the crime elements, i.e. burning the forest by starting fire, is a deliberate and intentional action.

What is the solution for allowing forest fires for scientific purposes in order to 
prevent bigger damages? First of all, is it really necessary to start a fire for drill? Is it obligatory? Considering today's modern facilities such as computer technology, simulation, etc., is this kind of action essential? This should be evaluated.

Determination of the fire simulation models which play a crucial role in preventing the larger fire and the fire behaviours that are used to construct these simulation models are very important. Fire behaviours can also be determined using data that was obtained from natural fires. But, many environmental conditions affect natural fires. Firstly, these conditions must be analyzed. Because of that, detection with natural fires are usually very difficult during the fires. In many countries, experimental fires are widely used in combination with natural fires (Küçük et al. 2010).

In order to prevent larger fires Test fires are vital to develop of the simulation models in today's technology. While preparing a general arrangement, the permission for experimental fires by the fire crew should be given by a commission rather than by a single person.

Trees are also burnt in fires by starting crossing fire, which is accepted legal. First of all, starting crossing fire must be inevitable and this may be associated with the necessity in the context of penal law. With regard to burning the surface fuels, it is argued that the act of burning does not damage the forest, it even benefits it. This is, at least, made possible by arranging this subject in the general regulatory transaction. In addition, the method of burning the surface fuel with prescribed fire is used in the United States and some countries located in the Mediterranean climate zone (Brockway and Lewis, 1997; Carter and Foster, 2003; Moreira et al. 2003).

Allowing starting fire for scientific purposes on forest lands cannot be evaluated under the title of operation of the forests, because a good manager should be prudent and specialised in his field who can understand legal and actual situations. Compared to the private law, a public officer working in forest organization must firstly be a better manager. Allowing starting a fire for scientific purposes on forest lands and performing such act may mean violation of environmental right which is also governed by the Constitution. Environmental right which is a tool for protection of health, integrity of the body and the life turns into condition of realisation and existence of the freedoms through creating a common space and reconciliation environment for other freedoms, as a balanced and adaptable right which creates a kind of ownership right on the common wealth of the humanity (Kaboğlu, 1996). In according to the environmental right which is built on the principle of "equality" based on the argument that the environment is "the common property of everyone", which is adopted for the first time in United Nations Environment Conference held in Stockholm, capital of Sweden, in 1972, it is aimed to make the nature favourable for living for present and future generations and to ensure that everyone benefits from it on equal terms (Kaboğlu, 1996). Thus, such an action which may damage the environment and forest, which is owned by everyone and is the common property, may result in violation of environmental right.

\section{Conclusion}

Considering the Constitution and the provisions of other legislation, the administration is not authorised to allow starting fire on forest lands, even for scientific purposes. Allowing such an act without any legal arrangement will also conflict with the principle of legality of the administration. Absence of such an arrangement on allowing mentioned act will make the administrative action illegal in terms of the elements of power, purpose and subject. If such act is allowed this way, this may require criminal and civil liability of the public officer allowing the act. However, if this kind of act is inevitable for developing techniques and procedures in order to prevent bigger forest fires and extinguish the forest fires with less damage, then there must be an arrangement in place which at least ensures legal certainty in order to relieve the criminal and civil liability of the manager allowing it and of those performing the act, and general arrangement allowing this should grant mentioned power to allow such act to a 
commission as a board, not to a single person.

\section{References}

Akkaş, M. E., Bucak, C., Boza, Z., Erkonat, H., Bekereci, A., Erkan, A., Cebeci, C. (2008). Büyük Orman Yangınlarının Meteorolojik Veriler Işığında İncelenmesi, T.C. Çevre ve Orman Bakanlığı, Ege Ormancılık Araştırma Müdürlüğü, Teknik Bülten, 36, İzmir.

Akkuzu, E., Küçük, Ö., Evcin, Ö. (2012). Forest Fire Effects On Mammalian Species. the 7th International Conference on Wood and Fire Safety, 13 - 16 May 2012, Proceedings Book, Slovakia.

Akyılmaz, B. 2000. İdari Usul İlişkileri Işı̆̆ında İdari İşlemin Yapılış Usulü. Yetkin Yayınları, 2000, s. 88-89.

Akyılmaz, B., Sezginer, M., Kaya, C. (2009). Türk Idare Hukuku, Ankara. 5.130.131

Aras, C. (2013). Açılamalı-İçtihatlı Orman Kanunu, ISBN:9786051461182, Adalet Yayınevi, Ankara

Balta T. B. (1970). İdare Hukuku I: Genel Konular, Ankara, AÜSBF Yay.,19701972

Bilgili, E. (1998). Yangin Amenajmanı Planlamalarında Yanici Madde Amenajmanını Rolü, Orman Yangınları Politikası ve Planlaması Eğitim Kursu, Ankara.

Bilgili, E., Küçük, Ö., Sağlam B. (2002). Yangın Davranışının Tahmini ve Yangınlarla Mücadeledeki Önemi, Kastamonu Orman Fakültesi Dergisi, 2 (2).

Brockway D. G., Lewis C. E. (1996). Longterm Effects of Dormant-season Prescribed Fire on Plant Community Diversity, Structure and Productivity in a Longleaf Pine Wiregrass Ecosystem, Forest Ecology and Management, 96, 167-183.

Can, O. (2005). Belirlilik İlkesine Anayasal Bakış, Erzincan Hukuk Fakültesi Dergisi, 9 (1-2), 89-125.

Carter, M. C., Foster, C. D. (2003). Prescribed Burning and Productivity in Southern Pine Forests: a Review, Forest Ecology and Management, 191, 93-109

Catrya, F.X., Regoa F., Moreira F., Fernandes P.M. , Pausas J.G. (2010).
Post-fire tree mortality in mixed forests of central Portugal, Forest Ecology and Management, 260, 1184-1192.

Erdoğan, M. (2012). Insan Haklart Teorisi ve Hukuku, ISBN:9944769631, Orion Kitabevi, 3. Bask1, Ankara.

Eron, Z. (1988). Orman Yangınları ve Mücadele Yöntemleri, Ormancilık Araştırma Enstitüsü Yayınları Muhtelif Yayınlar Serisi : 56 Ekim 1988-Ankara.

Evcin, Ö., Akkuzu, E., Küçük, Ö., Ünal, S. (2014). Responses of Reptiles, International Forest Fire Conference in Black Sea Region, 6-8 November 2014, Kastamonu.

Gözler, K. (2009). İdare Hukuku, Ekin Yayınevi, Bursa.

Gölcüklü, F., Gözübüyük, Ş. (2002). Avrupa Insan Hakları Sözleşmesi ve Uygulaması, Turhan kitabevi, Ankara

Gülan, A. (1988). Kamu Hizmeti Kavram1, İdare Hukuku ve İlimleri Dergisi, Y1l 9, Say1 1-3, İstanbul, s.148.

Gülan, A. (1999). Kати Mallarından Yararlanma Usullerinin Tabi Olduğu Hukuki Rejim, İstanbul: Alfa Yayıncılık.

Günday, M. (2015). İdare Hukuku, İmaj yayınevi, 10. Bask1, Ankara.

Güneş, T. (1965). Türk Pozitif Hukukunda Yürütme Organının Düzenleyici Işslemleri, Ankara, AÜSBF Yayınları No: 191-173, Sevinç Matbaası, Ankara.

Kaboğlu, İ, Ö. (1996). Çevre Hakkl, Tümüyle Yenilenmiş ve Genişletilmiş Üçüncü Baskı, Ankara, İmge Kitabevi, s. 29-30.

Küçük, Ö., Bilgili E., Durmaz., D. B. (2005). Yangin Potansiyelinin Belirlenmesinde Yanıc1 Madde Haritalarının Önemi, Süleyman Demirel Üniversitesi Orman Fakültesi Dergisi Seri: A, Say1: 1, Y11: 2005,ISSN 13027085,S.104-116.

Küçük, Ö., Bilgili, E. (2007). Coğrafi Bilgi Sistemleri (CBS) Yardımıla Yangın Davranışının Uygulamaya Aktarılması: Kastamonu Örneği. Kastamonu Üniversitesi Orman Fakültesi Dergisi, 7(1), 262-273.

Küçük Ö., Bilgili E., Sağlam B, Dinç Durmaz B., Baysal, İ. (2010). Türkiye'de Yangın Davranışının Belirlenmesine Yönelik Yapılan Deneme Yangınları, III. 
Ulusal Karadeniz Ormancilik Kongresi, 20-22 Mayıs 2010, Cilt: III Sayfa: 12511261.

Küçük, Ö., Aktepe, N., (2017). Effect of Phenolic Compounds on the Flammability in Forest Fires, International Journal of Engineering Sciences \& Research Technology, 6(4), 320- 327.

Moreira, F., Delgado, A., Ferreira, S., Borralho R., Oliveira, N., Inacio, M., Silva, S. J., Rego, F. (2003). Effects of Prescribed Fire on Vegetation Structure And Breeding Birds in Young Pinus Pinaster Stands of Northern Portugal, Forest Ecology and Management, 184, 225-237.

Orman Genel Müdürlüğü (2017). Ulusal Ormancılık ve $\mathrm{Su}$ Şurası, Ormanların Korunması, Çalışma Grubu 8, Ankara.

Özbudun, E. (2004). Türk Anayasa Hukuku, Yetkin Yayınları, ISBN: 978-975-464873-7 Ankara.

Şengönül, K. (1985). Orman Yangınları ile Toprak Isınması Arasındaki İlişkiler ve Yangınların Toprak Özellikleri Üzerine Etkileri., İstanbul Üniversitesi Orman Fakültesi Dergisi, Seri:B, 35 (2), İstanbul.

Tavşanoğlu Ç. (2010). Yangınlar ve Biyoçeşitlilik, NTV Bilim, Ağustos 2010

Yıldırım, T., Yasin, M., Kaman, N., Özdemir, E., Üstün, G., Tekinsoy Ö.,O. (2015). İdare Hukuku, Güncellenmiş 6. Baskı, On İki Levha Yayınları, İstanbul. 